\title{
PENERAPAN MODEL PEMBELAJARAN SAINTIFIK UNTUK MENINGKATKAN HASIL BELAJAR PESERTA DIDIK PADA KONSEP USAHA DAN ENERGI
}

\author{
Mursalin \\ Jurusan Fisika, Fakultas MIPA,Universitas Negeri Gorontalo \\ Jl. Jenderal Sudirman No. 6 Kota Gorontalo, 96128; \\ e-mail: mursalin@ung.ac.id
}

\begin{abstract}
ABSTRAK: Artikel hasil penelitian ini memaparkan tentang upaya peningkatan hasil belajar kognitif pada konsep Usaha dan Energi dengan menggunakan model pembelajaran saintifik. Penelitian ini dilakukan secara kuasi-eksperimen dengan rancangan one group pretest-posttest. Sampel penelitian menggunakan cluster random sampling dari peserta didik kelas XI salah satu SMA di Provinsi Gorontalo. Instrumen pengumpul data yang digunakan adalah tes tertulis bentuk uraian, lembar penilaian proyek, lembar penilaian sikap dan angket. Analisis data dilakukan dengan rerata gain ternormalisasi dan persentase. Hasil penelitian mengungkap bahwa penerapan model pembelajaran saintifik efektif meningkatkan hasil belajar kognitif peserta didik. Selain itu, model pembelajaran ini juga mampu meningkatkan penilaian proyek dan sikap jujur, disiplin, kerjasama, rasa ingin tahu, dan tanggung jawab peserta didik.
\end{abstract}

Kata Kunci: pembelajaran saintifik, hasil belajar, usaha dan energi.

ABSTRACT: This one group pretest-posttest experiment was aimed to improve students' learning outcome on the topic of work and energy with using the scientific learning model. The subjects were selected using cluster random sampling from the high school students in Gorontalo. The instruments used to collect the data included pretest, posttest, project observation sheet, attitude observation sheet and questionnaires. The data were analyzed using the gain normalized average and persentage. The results show that the application of scientific learning model is effective to improve the students' learning outcome on the topic of work and energy. This learning model also to improve the project assessment and attitude assessment as the honest, discipline, cooperation, curiosity, and responsible.

Keywords: cycle learning, concepts understanding, science process skills.

\section{PENDAHULUAN}

Sains termasuk fisika didasarkan pada pengukuran dan perbandingan (Halliday \& Resnick, Walker, 2014). Fisika menurut Serwey \& Jewett (2009) didasarkan pada hasil pengamatan eksperimental dan pengukuran kuantitatif. Pendapat lain, fisika adalah selain sebagai produk ilmiah seperti fakta, konsep, prinsip, teori, hukum, 
model, dan generalisasi, juga merupakan proses dan sikap ilmiah yakni berbagai keterampilan dan sikap yang digunakan untuk memperoleh dan mengembangkan produk-produk sains (Rutherford \& Ahlgren, 1990; NRC, 1996).

Permasalahan utama dalam pembelajaran fisika baik sebagai proses maupun produk adalah rendahnya upaya pengembangan proses berpikir yang dapat menuntun peserta didik untuk mengonstruksi pengetahuannya dalam rangka meningkatkan komptensinya. Proses pembelajaran fisika yang umum dilakukan di sekolah lebih banyak menggunakan metode ceramah sehingga mata pelajaran fisika terkesan sebagai materi hafalan dan peserta didik hanya pasif mengonstruksi pengetahuannya sehingga berakibat peserta didik tidak mampu menunjukkan penguasaan konsep secara utuh yang ditandai dengan hasil belajar rendah. Hal ini sesuai pendapat Liliasari (2007) yang menyebutkan proses pembelajaran IPA termasuk mata pelajaran fisika di sekolah umumnya dilakukan secara verbalistik dan disajikan melalui metode ceramah sehingga menuntut siswa mengenal istilah-istilah IPA secara hafalan tanpa makna.

Konsep usaha dan energi merupakan salah satu konsep penting yang diajarkan dalam kurikulum sekolah. Namun kenyataannya, tidak sedikit peserta didik yang mengalami kesulitan dalam menguasai dan memecahkan berbagai permasalahan dalam kehidupannya terutama yang berkaitan dengan konsep usaha dan energi. Hal ini disebabkan karena peserta didik tidak mampu mengonstruksi sendiri pengetahuannya dalam proses belajarnya sehingga mengalami kesulitan dalam memecahkan dan mencari solusinya mengapa hal tersebut terjadi seperti itu.

Upaya untuk meningkatkan hasil belajar peserta didik khususnya pada konsep usaha dan energi merupakan suatu keharusan yang sangat mendesak. Proses pembelajaran yang diduga dapat mengatasi permasalahan tersebut adalah penerapan model pembelajaran saintifik. Dikatakan demikian karena dalam model pembelajaran saintifik, peserta didik tidak hanya dituntut untuk membaca materi pelajaran tetapi harus mengontruksi pengetahuannya sendiri dengan menggunakan langkah-langkah pembelajaran mengamati, menanya, mengumpulkan informasi, mengasosiasikan, dan mengomunikasikan materi yang dipelajari (Depdiknas, 2013). Selain itu, peserta didik diminta untuk merefleksikan dan mengevaluasi kinerjanya dalam rangka meningkatkan pemahamannya dan mendorong kemampuan belajar yang lebih tinggi.

Berdasarkan uraian di atas, maka tujuan penelitian ini adalah untuk mengetahui peningkatan hasil belajar kognitif pada konsep Usaha dan Energi dengan penerapan model pembelajaran saintifik.

\section{METODE}

Penelitian dengan metode quasi-exsperiment ini menggunakan rancangan one group pretest-posttest (Sugiyono, 2006; Cohen \& Manion, 1994). Desain penelitian ini disajikan sebagaimana pada Tabel 1.

Tabel 1: Desain Penelitian

\begin{tabular}{cccc}
\hline Pertemuan ke & Pretes & Perlakuan & Postes \\
\hline 1 & $\mathrm{~T}$ & $\mathrm{X}$ & $\mathrm{T}$ \\
\hline 2 & $\mathrm{~T}$ & $\mathrm{X}$ & $\mathrm{T}$ \\
\hline 3 & $\mathrm{~T}$ & $\mathrm{X}$ & $\mathrm{T}$ \\
\hline 4 & $\mathrm{~T}$ & $\mathrm{X}$ & $\mathrm{T}$ \\
\hline
\end{tabular}


Ket: $\mathrm{T}=$ Tes sebelum dan sesudah perlakuan dan $\mathrm{X}=$ Model pembelajaran saintifik

Paparan pada Tabel 1 menunjukkan bahwa penelitian dilakukan sebanyak 4 (empat) kali pertemuan pada konsep Usaha dan Energi. Subjek penelitian dipilih dengan teknik cluster random sampling dari populasi peserta didik kelas XI pada salah satu SMA di Provinsi Gorontalo dengan sampel sejumlah 30 orang. Instrumen pengumpul data yang digunakan adalah tes tertulis bentuk uraian pada aspek kognitif, penilaian proyek dari tugas-tugas, penilaian sikap, dan angkat

Pengumpulan data diawali dengan kegiatan pretes pada setiap pertemuan untuk melihat tingkat homogenitas pengetahuan awal peserta didik. Pasca perlakuan dengan model pembelajaran sanitifik diberikan postes dan angket. Pretes dan postes bertujuan memaparkan pengaruh model pembelajaran sanitifik terhadap hasil belajar peserta didik pada aspek kognitif, sedangkan angket bertujuan untuk memaparkan tanggapan peserta didik terhadap penerapan model pembelajaran sanitifik. Penilaian proyek terhadap tugas-tugas yang diselesaikan peserta didik dalam waktu tertentu dengan indikator merumuskan masalah, melakukan pengamatan, menafsirkan atau mengolah data, mengomunikasikan, dan konten materi. Sementara penilaian sikap dilakukan dari skala 1 sampai 3 ( 1 = kurang, $2=$ cukup, $3=$ baik) pada indikator jujur, disiplin, kerjasama, rasa ingin tahu, dan tanggung jawab.

Analisis peningkatan hasil belajar peserta didik pada konsep Usaha dan Energi dilakukan dengan menghitung rerata gain ternormalisasi pada setiap pertemuan dengan menggunakan persamaan Hake (1998). Nilai hitung rerata gain ternormalisasi dikategorisasikan sebagaimana pada Tabel 2.

Tabel 2 : Kategori Nilai Hitung Rerata Gain Ternormalisasi

\begin{tabular}{ccc}
\hline Persamaan Hake & No. & Kategori \\
\hline$<g>=\frac{\left\langle S_{\text {post }}\right\rangle-\left\langle S_{\text {pre }}\right\rangle}{100-\left\langle S_{\text {pre }}\right\rangle}$ & 1. & $<g>\geq 0,7=$ Tinggi \\
& 2. & $0,3 \leq<g><0,7=$ Sedang \\
& & $<0,3=$ Rendah \\
\hline
\end{tabular}

Ket: $\left\langle S_{\text {post }}\right\rangle=$ skor rerata hasil post-tes dan $\left\langle S_{\text {pre }}\right\rangle=$ skor rerata hasil pre-tes

\section{HASIL DAN PEMBAHASAN}

Rerata skor pretes, postes, dan gain hasil belajar peserta didik pada konsep Usaha dan Energi untuk setiap pertemuan disajikan sebagaimana pada Tabel 3.

Tabel 3: Rerata skor pretes, posttes, dan gain hasil belajar peserta didik

\begin{tabular}{ccccc}
\hline \multirow{2}{*}{ Pertemuan ke } & \multicolumn{2}{c}{ Rerata Skor } & \multicolumn{2}{c}{$\langle\mathrm{g}\rangle$} \\
\cline { 2 - 5 } & Pretes & Postes & Nilai & Kategori \\
\hline 1 & 33,52 & 71,49 & 0,57 & Sedang \\
\hline 2 & 40,45 & 79,80 & 0,66 & Sedang \\
\hline
\end{tabular}




\begin{tabular}{lllll}
\hline 3 & 42,53 & 82,75 & 0,70 & Tinggi \\
\hline 4 & 41,38 & 83,82 & 0,72 & Tinggi \\
\hline
\end{tabular}

Paparan Tabel 3 menunjukkan paling rendah rerata skor pretes, postes, dan gain ternomalisasi di pertemuan pertama. Hal ini diduga terjadi karena peserta didik belum terbiasa melakukan proses belajar dengan langkah-langkah pembelajaran saintifik, yakni mengamati, menanya, mengumpulkan informasi, mengasosiasikan, dan mengomunikasikan materi yang dipelajari. Tetapi pada pertemuan berikutnya, peserta didik semakin menyesuaikan diri terhadap model pembelajaran saintifik yang ditunjukkan dengan rerata postes dan gain ternormalisasi semakin meningkat. Dengan demikian, penerapan model pembelajaran saintifik pada konsep Usaha dan Energi efektif untuk meningkat hasil belajar peserta didik. Hasil ini sesuai pendapat Mursalin (2014) bahwa model pembelajaran Predict-Observe-Explain (salah satu model pembelajaran yang direkomendasikan dalam kurikulum 2013 mampu meningkatkan pemahaman konsep dan meminimalkan miskonsepsi peserta didik.

Berdasarkan hasil rubrik penilaian proyek diperoleh persentase peserta didik yang memperoleh kategori baik, cukup, dan kurang terhadap indikator merumuskan masalah, mengamati, menafsirkan atau mengolah data, mengomunikasikan, dan konten materi disajikan sebagaimana pada Tabel 4.

Tabel 4: Persentase peserta didik yang memperoleh penilaian proyek berkategori baik, cukup, dan kurang pada setiap pertemuan.

\begin{tabular}{llccc}
\hline \multirow{2}{*}{ No. Indikator } & \multicolumn{3}{c}{ Persentase } \\
\cline { 2 - 5 } Pertemuan 1 & Baik & Cukup & Kurang \\
$1 \quad$ Merumuskan masalah & 23 & 40 & 37 \\
2 & Melakukan pengamatan & 80 & 10 & 10 \\
3 & Menafsirkan atau mengolah data & 30 & 17 & 53 \\
4 & Mengomunikasikan & 40 & 10 & 50 \\
5 & Konten materi & 50 & 20 & 30 \\
\hline Pertemuan 2 & & & \\
$1 \quad$ Merumuskan masalah & 47 & 30 & 23 \\
$2 \quad$ Melakukan pengamatan & 83 & 10 & 7 \\
3 & Menafsirkan atau mengolah data & 33 & 23 & 44 \\
4 & Mengomunikasikan & 50 & 17 & 33 \\
5 & Konten materi & 63 & 27 & 10 \\
\hline Pertemuan 3 & & & \\
1 & Merumuskan masalah & 73 & 17 & 10 \\
2 & Melakukan pengamatan & 87 & 10 & 3 \\
3 & Menafsirkan atau mengolah data & 50 & 30 & 20 \\
$4 \quad$ Mengomunikasikan & 63 & 23 & 14 \\
5 & Konten materi & 73 & 20 & 7 \\
\hline Pertemuan 4 & & & \\
1 & Merumuskan masalah & 80 & 20 & 0 \\
2 & Melakukan pengamatan & 93 & 7 & 0 \\
$3 \quad$ Menafsirkan atau mengolah data & 70 & 20 & 10 \\
4 & Mengomunikasikan data & 90 & 7 & 3 \\
\hline
\end{tabular}




\begin{tabular}{lllll}
\hline 5 & Konten materi & 90 & 10 & 0 \\
\hline
\end{tabular}

Hasil analisis data sebagaimana disajikan pada Tabel 4 menunjukkan persentase peserta didik yang memperoleh penilaian proyek berkategori baik pada setiap indikator meningkat dari setiap pertemuan. Pada pertemuan pertama, hanya indikator melakukan pengamatan yang memperoleh persentase penilaian peserta didik berkategori baik di atas 75\% (kategori baik minimal). Hal ini diduga terjadi karena peserta didik belum terlatih melakukan kegiatan merumuskan masalah, menafsirkan atau mengolah data, mengomunikasikan data, dan menganalisis konten materi. Namun setelah berlatih ternyata hanya indikator menafsirkan atau mengolah data masih memperoleh persentase penilaian peserta didik berkategori baik di bawah $75 \%$. Dengan kata lain, setelah pertemuan keempat masih terdapat 3 orang $(10 \%)$ peserta didik pada indikator menafsirkan atau mengolahan data pengamatan dan 1 orang (3\%) peserta didik pada indikator mengomunikasikan data pengamatan yang perlu mendapat perhatian khusus pada proses pembelajaran berikutnya karena masih memperoleh persentase penilaian berkategori kurang.

Hasil penilaian sikap ketika peserta didik mengajupkan pendapat, pertanyaan, mengambil keputusan, menyajikan laporan, mengumpulkan tugas serta ketika berinteraksi dengan teman dan lingkungannya diperoleh persentase peserta didik berkategori baik, cukup, dan kurang pada indikator jujur, disiplin, kerjasama, rasa ingin tahu, dan tanggung jawab disajikan sebagaimana pada Tabel 5 .

Tabel 5: Persentase peserta didik yang memperoleh penilaian sikap berkategori baik, cukup, dan kurang pada setiap pertemuan.

\begin{tabular}{llccc}
\hline \multirow{2}{*}{ No. } & \multirow{2}{*}{ Indikator } & \multicolumn{3}{c}{ Persentase } \\
\cline { 2 - 5 } Pertemuan 1 & Baik & Cukup & Kurang \\
$1 \quad$ Jujur & 50 & 27 & 23 \\
2 & Disiplin & 53 & 33 & 14 \\
3 & Kerjasama & 60 & 23 & 17 \\
$4 \quad$ Rasa ingin tahu & 30 & 20 & 50 \\
$5 \quad$ Tanggung jawab & 43 & 30 & 27 \\
\hline Pertemuan 2 & & & \\
$1 \quad$ Jujur & 57 & 33 & 10 \\
$2 \quad$ Disiplin & 63 & 30 & 7 \\
$3 \quad$ Kerjasama & 70 & 20 & 10 \\
$4 \quad$ Rasa ingin tahu & 50 & 17 & 33 \\
5 & Tanggung jawab & 60 & 23 & 17 \\
\hline Pertemuan 3 & & & \\
$1 \quad$ Jujur & 70 & 23 & 7 \\
$2 \quad$ Disiplin & 73 & 24 & 3 \\
$3 \quad$ Kerjasama & 77 & 20 & 3 \\
$4 \quad$ Rasa ingin tahu & 57 & 27 & 16 \\
5 & Tanggung jawab & 80 & 10 & 10 \\
\hline Pertemuan 4 & & & \\
1 & Jujur & 83 & 14 & 3 \\
\hline
\end{tabular}




\begin{tabular}{clcccc}
\hline \multirow{2}{*}{ No. } & & \multicolumn{3}{c}{ Persentase } \\
\cline { 3 - 5 } & & Indikator & 87 & 10 & 3 \\
\hline 2 & Disiplin & 97 & 3 & 0 \\
3 & Kerjasama & 77 & 20 & 3 \\
4 & Rasa ingin tahu & 93 & 7 & 0 \\
5 & Tanggung jawab & & \\
\hline
\end{tabular}

Paparan data dalam Tabel 5 menunjukkan persentase peserta didik yang memperoleh penilaian sikap berkategori baik pada setiap indikator meningkat dari setiap pertemuan. Pada pertemuan pertama dan kedua semua indikator memperoleh persentase penilaian peserta didik berkategori baik di bawah $75 \%$ (kategori baik minimal). Ini berarti peserta didik harus dilatih terus agar sikap jujur, disiplin, kerjasama, rasa ingin tahu, dan tanggung jawab meningkat. Hal ini dapat ditunjukkan setelah peserta didik berlatih hingga pertemuan keempat, semua indikator telah memperoleh persentase penilaian berkategori baik di atas $75 \%$, namun masih ada 1 orang (3\%) peserta didik yang perlu mendapat perhatian khusus pada proses pembelajaran berikutnya karena masih memperoleh penilaian berkategori kurang yakni pada indikator jujur, disiplin, dan rasa ingin tahu.

Tanggapan peserta didik untuk setiap pernyataan angket mengenai penerapan model pembelajaran saintifik pada konsep Usaha dan Energi menunjukkan bahwa seluruh peserta didik menyatakan model pembelajaran saintifik menantang dan menggunakan paradigma student centered; dapat meningkatkan minat, daya tarik dan motivasi saya untuk mempelajari materi fisika; dan hasil belajar saya dalam mata pelajaran fisika meningkat. Hampir seluruh peserta didik menyatakan bahwa penerapan model pembelajaran saintifik, kemampuan saya dalam mengamati, menanya, mengumpulkan informasi, menyimpulkan, dan mengomunikasikan materi pelajaran meningkat; dan melatih saya untuk merumuskan masalah dan menafsirkan kecenderungan data, sebagaimana disajikan pada Tabel 6.

Tabel 6: Persentase tanggapan peserta didik terhadap model pembelajaran saintifik

\begin{tabular}{|c|l|c|}
\hline No & \multicolumn{1}{|c|}{ Pernyataan Angket } & $\begin{array}{c}\text { Setuju } \\
(\%)\end{array}$ \\
\hline 1. & $\begin{array}{l}\text { Model pembelajaran saintifik menantang dan menggunakan } \\
\text { paradigma student centered }\end{array}$ & 100 \\
\hline 2. & $\begin{array}{l}\text { Model pembelajaran saintifik dapat meningkatkan minat, daya tarik } \\
\text { dan motivasi saya untuk mempelajari materi fisika }\end{array}$ & 100 \\
\hline 3. & $\begin{array}{l}\text { Melalui model pembelajaran saintifik, kemampuan saya dalam } \\
\text { mengamati, menanya, mengumpulkan informasi, menyimpulkan, } \\
\text { dan mengomunikasikan materi pelajaran meningkat }\end{array}$ & 97 \\
\hline 4. & $\begin{array}{l}\text { Melalui model pembelajaran saintifik, melatih saya untuk } \\
\text { merumuskan masalah dan menafsirkan kecenderungan data }\end{array}$ & 90 \\
\hline 5. & $\begin{array}{l}\text { Melalui model pembelajaran saintifik, hasil belajar saya dalam mata } \\
\text { pelajaran fisika meningkat }\end{array}$ & 100 \\
\hline
\end{tabular}




\section{SIMPULAN}

Hasil penelitian menunjukkan adanya peningkatan hasil belajar peserta didik pada konsep Usaha dan Energi pada setiap pertemuan pasca penerapan model pembelajaran saintifik. Dengan kata lain, model pembelajaran saintifik mampu meningkatkan hasil belajar peserta didik, mampu meningkatkan kegiatan peserta didik dalam merumuskan masalah, melakukan pengamatan, menafsirkan atau mengolah data, mengomunikasikan data, dan konten materi; serta mampu meningkatkan sikap jujur, disiplin, kerjasama, rasa ingin tahu, dan tanggung jawab peserta didik. Penelitian ini direkomendasikan pada setiap topik pembelajaran fisika dalam upaya membiasakan peserta didik untuk melakukan proses belajar dengan langkah-langkah pembelajaran dari mengamati, menanya, mengumpulkan informasi, menyimpulkan, dan mengomunikasikan materi pelajaran.

\section{DAFTAR PUSTAKA}

Cohen, L. \& Manion, L. (1994). Research Methods in Education, Fourth Edition. London and New York : Routledge.

Depdiknas (2013). Lampiran Peraturan Menteri Pendidikan dan Kebudayaan Nomor 69 Tahun 2013 tentang Kerangka Dasar dan Struktur Kurikulum Sekolah Menengah Atas/Madrasah Aliyah. Jakarta : Pusat Kurikulum dan Perbukuan Balitbang Kemendikbud Republik Indonesia.

Hake, R. R. (1998). Interactive Engagement Versus Tradisional Methods: A Six Thousand Student Survey of Mechanics Test Data For Introductory Physics Course, Am. J. Phys. 66 (1) $64-74$.

Halliday, D., Resnick, R. \& Walker, J. (2014). Fundamentals of Physics, 10th Edition. New York : John Wiley \& Sons.

Liliasari. (2007). Scientific Concepts and Gereric Science Skills Relationship in the 21st Century Science Education. Makalah Seminar International Pendidikan IPA. Bandung, 27 Oktober 2007.

Mursalin. (2014). Meminimalkan Miskonsepsi pada Materi Rangkaian Listrik dengan Pembelajaran Predict-Observe-Explain. Malang: Jurnal Ilmu Pendidikan, Jilid 20, No. 1. Hal 94-99, ISSN 0215-9643.

NRC. (1996). National Science Education Standard. Washington DC: National Academy Press., (1996).

Rutherford, F. J. \& Ahlgren, A. (1990). Science For All Americans. New York: Oxford University Press.

Serwey, R. A. \& Jewett, Jr. J. W. (2009). Fisika untuk Sains dan Teknik. Edisi 6. Jakarta : Salemba Teknika.

Sugiyono. (2006). Metode Penelitian Pendidikan; Pendekatan Kuantitatif, Kualitatif dan R \& D. Bandung : Alfabeta. 